\title{
Comparative Stress Dynamics of Brood Stock Striped Bass Morone saxatilis Associated with Two Capture Techniques
}

\author{
Reginal M. Harrell ${ }^{1}$ and Mark A. Moline ${ }^{2}$ \\ Center for Environmental and Estuarine Studies, Horn Point Environmental Laboratory. \\ Cambridge, Maryland USA
}

\begin{abstract}
Mature striped bass (Morone saxatilis) were collected from the spawning reaches of the Choptank River, Maryland for the purpose of evaluating stress effects associated with capture. Two commonly used capture devices were evaluated-gillnetting and electrofishing. Results indicated that stress, as measured by changes in plasma corticosteroid and chloride concentrations, was significantly lower and recovery time quicker in those fish captured by electrofishing compared to gillnetting. By the end of the study period ( $48 \mathrm{~h}$ ), those fish captured by electrofishing had recovered from the initial capture shock as evidenced by corticosteroid levels returning to near baseline levels. Conversely, at 48 h post-capture, those fish captured by gillnetting exhibited severe hypochloremia and elevated corticosteroid levels approaching that of the initial stress associated with capture.
\end{abstract}

The culture of striped bass (Morone saxatilis) is, by and large, dependent on the capture of wild brood fish for its source of seed stock. This capture is usually associated with the time of natural spawning and is generally located at or near the spawning grounds. Capture techniques involve various forms of netting, hook and line, traps, or electrofishing (Harrell 1984; Harrell et al. 1990; Yeager et al. 1990). Until recently in Maryland, the most commonly used brood fish capture device has been gillnetting. Most states however, prefer the use of electrofishing whenever possible. Culturists "feel" they achieve better spawning success and postspawning survival of brood fish using electrofishing due to putatively lower stress associated with capture. Maryland now uses electrofishing in conjunction with gillnetting.

Handling of striped bass in capture, transfer, and transport causes stress and can result in high mortality (Yeager et al. 1990).
The term "stress" as defined by Esch and Hazen (1978) is the effect of any environmental alteration or force that extends homeostatic or stabilizing processes beyond their normal limits at any level of biological organization. Fish release adrenocorticotrophic hormone from the adenohypophysis which stimulates the secretion of catecholamines (epinephrine and norepinephrine) and corticosteroids from the interrenal tissue in response to stress (Seyle 1950). Among the physiological changes caused by the release of these "stress hormones," especially the catecholamines, are dilation of the gill filamental arteries, an increase stroke volume of the heart, increased glycogen metabolism, and the depression of the immune response (Gratzek and Reinert 1984). Accompanying these responses is an increase of blood flow to muscle tissue for the "fight or flight" response described by Seyle (1950) which intuitively could effect poor survival of eggs due to the potential for reduced blood flow to the ovaries before ovulation.

Although the stress response is initially advantageous to fish, providing increased available energy for short term emergencies, long term exposure to stressful conditions may result in death from osmoregulatory 
dysfunction and lowered disease resistance (Lewis 1971; Wedemeyer 1972). Osmoregulatory dysfunction, characterized by decreased plasma electrolyte levels, results directly from a sustained increase in branchial blood flow, which in turn increases water uptake and ionic loss at the gills (Lewis 1971; Wedemeyer 1972). Lowered disease resistance in fish from exposure to stress may result from suppression of the immunological system expressed as a decreased inflammatory response consequent to elevation of plasma corticosteroid levels (Wedemeyer 1970; McLeay 1973; Mazeaud et al. 1977).

Stress dynamics associated with handling and confinement of fish are also well documented (Lewis 1971; Wedemeyer 1972; Tomasso et al. 1980; Wedemeyer and McLeay 1981; Davis and Parker 1983; Davis et al. 1982, 1984; Gratzek and Reinert 1984). It is reasonable to assume that stress potentially can influence spawning success of captured wild or even domesticated brood stock.

This study examined the stress dynamics and response of striped bass brood fish caught by the two capture techniques currently used in Maryland, and evaluated if electrofishing is physiologically less stressful than gillnetting. Changes in plasma cortisol and plasma chloride concentrations were measured as indicators of the stress response.

\section{Materials and Methods}

In April and May of 1986 and 1987, random populations of sexually mature striped bass (mean weight $=2.1 \mathrm{~kg}$ and $10.6 \mathrm{~kg}$ for males and females respectively) were captured for analysis. Capture was by either a $30 \mathrm{~m} \times 2.7 \mathrm{~m} \times 4 \mathrm{~cm}$ bar mesh drift gill net or with a variable voltage pulsating control electroshocker (Smith-Root Model GPP-7.5) usually operated between 360 and 720 volts DC and $8-10$ amperes. All collections were made in the area of Ganey's Wharf, Caroline County, on the Choptank River, Maryland, a tributary of the Chesapeake Bay.
Drift gill nets were deployed by boat the last hour before and during slack tide (preferably the last hour of ebb tide). Time between first setting the net and retrieval averaged 20 minutes. Electrofishing occurred generally during the same time on alternate days. Usually less than one minute after exposure to the electrical stimulus, stunned fish on the surface were collected with dipnets. After capture by either method, individuals were placed into an $800 \mathrm{~L}$ holding tank on the capture vessel and within onehalf hour were back at the dock at Ganey's Wharf. The boat holding tank was filled with water from the capture source which circulated within the tank through the use of a small pump connected to the boat's battery. Dissolved oxygen concentrations in the boat holding tank remained above $6.0 \mathrm{mg} /$ $\mathrm{L}$, and temperature during spawning season ranged from 15-18 C. No other treatment was added to the water.

All fish were captured at or near Ganey's Wharf, transported back to the staging area, and held in tanks filled with flow-through river water. River water was filtered through a rapid sand filter before entering the tanks. No other treatment to either the fish or water was applied.

Salinity in the collection areas ranged from 0 to $0.8 \mathrm{ppt}$, while the shore holding facility, located upstream from the capture sites, had no detectable salinity with hardness values from $100-300 \mathrm{mg} / \mathrm{L}$. Water temperature of the shore holding facility was the same as the capture site.

\section{Experimental Design}

The two methods of capture, electrofishing and gillnetting, were the experimental treatments. The intent of the evaluation was to measure the level of the initial response of the fish to stress (capture) and relate recovery time to the capture technique.

Experimental protocol included removing approximately $1.5 \mathrm{cc}$ of blood with ammonium heparin-coated syringes from the caudal vessel in the haemal arch. Sample time of blood samples was pre-established 
as immediately at capture, 1, 2, 3, 6, 12, 24, and $48 \mathrm{~h}$ after capture. Each sample time is represented by six new fish per treatment, and once captured and returned to the holding tanks on shore, the fish were not disturbed again until the scheduled bleeding time. Blood samples, other than those taken at capture, were immediately centrifuged and the plasma stored frozen $(-20 \mathrm{C})$ until analysis. Those blood samples taken at capture were stored in the syringe, on ice, until the blood was returned to the shore where it was treated the same as the other samples.

Hormone concentration was determined using the magnetic immunoassay technique described by Bennett and Rhodes (1986). This procedure, which uses ${ }^{125} \mathrm{I}$ labeled human cortisol, was found to have no significant differences between techniques developed by Murphy (1967) and Fagerlund (1970) (Nick Parker, Texas Cooperative Fishery Unit, Texas Tech University, Waco, Texas, personal communication). Plasma chloride concentrations were determined by amperometric-coulometric titration with a chloridometer.

Statistical analyses involved the use of analysis of variance (ANOVA) and least squared analysis of a split-plot design (Sokal and Rohlf 1982; SAS 1985). In all tests, a probability level of $\leq 0.05$ was considered significant.

\section{Results}

With both capture techniques, a capture effect was manifested by the first hour. Plasma corticosteroid levels increased rapidly the first hour and then remained elevated above capture levels for the entire study time (although not significant for the 2,24, and $48 \mathrm{~h}$ electrofishing sample [Table 1]). Highest levels of corticosteroid concentrations were found in the gillnetted fish and exceeded $300 \mathrm{ng} / \mathrm{ml} 75 \%$ of the sample times (Table 1). In contrast, those fish captured by electrofishing had corticosteroid levels exceeding $300 \mathrm{ng} / \mathrm{ml}$ only $12.5 \%$ of the time ( 1 of the 8 sample times) which was the first hour's measurement (Table 1).
TABLE L. Mean plasma corticosteroid concentrations $(\mathrm{ng} / \mathrm{ml}$ ) exhibited by brood stock striped bass (Morone saxatilis) captured by electrofishing or gillnetting in the Choptank River. Maryland. Hour 0 represents baseline or resting levels. Values in parentheses indicate $\pm S E: N=6$ fish per treatment per hour.

\begin{tabular}{ccc}
\hline $\begin{array}{c}\text { Time } \\
\text { from } \\
\text { capture } \\
\text { (h) }\end{array}$ & Electrofishing & Gillnetting \\
\hline 0 & $58.92(22.71)$ & $58.92(22.71)$ \\
1 & $302.03(44.80)^{\mathrm{a}}$ & $425.80(18.43)^{\mathrm{a}}$ \\
2 & $134.32(22.38)$ & $330.65(46.74)^{\mathrm{a}}$ \\
3 & $197.34(57.31)^{\mathrm{a}}$ & $387.42(51.77)^{\mathrm{a}}$ \\
6 & $194.68(49.45)^{\mathrm{a}}$ & $400.65(88.51)^{\mathrm{a}}$ \\
12 & $209.21(85.60)^{\mathrm{a}}$ & $178.45(50.71)^{\mathrm{a}}$ \\
24 & $81.06(16.99)$ & $184.93(58.13)^{\mathrm{a}}$ \\
48 & $95.11(22.38)$ & $381.13(65.80)^{\mathrm{a}}$ \\
\hline
\end{tabular}

a Values are significantly different (ANOVA) than the baseline (hour 0 ) levels.

In both capture methods, there was a decline in corticosteroid levels at hour 2, followed by an immediate secondary increase until hour 6 . Between 6 and 24 h post-capture, corticosteroid levels again decreased (recovery period) for the fish captured by both methods. Corticosteroid levels for the fish captured by gillnetting never approached baseline levels during the recovery period. In fact, with the fish captured by netting, there was a tertiary rise in corticosteroid levels between 24 and $48 \mathrm{~h}$.

Those fish captured by gillnetting consistently had plasma chloride levels below that of fish captured by electrofishing (Table 2). The plasma chloride levels for gillnetted fish were statistically lower than those fish captured by electrofishing at each sample time. Between 24 and $48 \mathrm{~h}$ post-capture, the gillnetted fish exhibited hypochloremia with plasma chloride levels declining to a low of $87.6 \mathrm{meq} / \mathrm{L}$. Unfortunately, the blood samples for the fish captured at $48 \mathrm{~h}$ by electrofishing were not available for chloride analysis.

At no time other than the $48 \mathrm{~h}$ sample for netting did any of the fish die in holding or during the bleeding process. All surviving fish were immediately released back into the 
TABLE 2. Mean plasma chloride concentrations / meq L) exhibited by brood stock striped bass (Morone saxatilis) captured by electrofishing or gillnetting in the Choptank River. Maryland. Capture value taken from fish captured by gillnetting. Hour 0 represents base. line or resting levels. Values in parentheses indicate $\pm S E: N=6$ fish per treatment per hour.

\begin{tabular}{cll}
\hline $\begin{array}{c}\text { Time } \\
\text { from } \\
\text { capture } \\
\text { (h) }\end{array}$ & Electrofishing & \multicolumn{1}{c}{ Gillnetting } \\
\hline 0 & $176.17(7.35)$ & $176.17(7.35)$ \\
1 & $209.33(8.42)^{\mathrm{a}}$ & $130.67(4.20)^{\mathrm{a}}$ \\
2 & $197.0(12.96)^{\mathrm{a}}$ & $146.0(7.16)^{\mathrm{a}}$ \\
3 & $202.17(3.77)^{\mathrm{a}}$ & $151.33(10.15)^{\mathrm{a}}$ \\
6 & $169.33(18.79)$ & $110.0(7.01)^{\mathrm{a}}$ \\
12 & $152.0(6.97)$ & $131.0(5.22)^{\mathrm{a}}$ \\
24 & $201.83(13.99)^{\mathrm{a}}$ & $144.17(6.0)^{\mathrm{a}}$ \\
48 & \multicolumn{1}{c}{-} & $87.66(9.18)^{\mathrm{a}}$ \\
\hline
\end{tabular}

a Values are significantly different (ANOVA) than the baseline (hour 0 ) levels.

river after the blood sample was taken. Of the 12 fish bled for the $48 \mathrm{~h}$ samples (both treatments combined), all six of the fish captured by electrofishing survived the handling and bleeding process and were released back to the Choptank River, while only two of the fish captured by gillnetting survived to be released.

\section{Discussion}

The stress response associated with capture was greatest in those fish gillnetted. Because there was a significant capture effect evident by the first hour post-capture, comparisons between treatments were unnecessary as an effect was already evident. Therefore, the evaluation in this study examined the recovery response within capture techniques.

For both capture techniques and purposes of this experiment, the corticosteroid and plasma chloride levels of fish initially captured by electrofishing were used to represent the baseline or resting levels - a concept referenced by Schreck (1976). This decision was based on the fact that it took an average of 25 minutes to recover the net once it was deployed. In the interim be- tween net deployment, recovery, and taking a blood sample, as much as 30 minutes usually elapsed. Tomasso et al. (1980) and Davis et al. (1982) found that measurable increases in plasma corticosteroid levels in striped bass and hybrid striped bass occurred within 15 minutes after being subjected to a stressor, and remained elevated for several hours after an initial exposure. Indeed, examination of those blood samples immediately taken from fish which were netted revealed a mean corticosteroid level of $243.98 \mathrm{ng} / \mathrm{ml}$ compared to $58.92 \mathrm{ng} / \mathrm{ml}$ for those fish captured by electrofishing. It was felt that if this rapid increase were true for fish in this study, results could be compromised by using blood taken from gillnetted fish immediately after the net was recovered as the baseline value. Therefore, the time required to collect the fish from the net and take the blood would, in actually, be a time artifact and could affect response analysis. Both baseline (resting) and upper levels found in those fish captured by electrofishing in this study are similar to previously reported values (Tomasso et al. 1980; Davis et al. 1982).

Likewise, the tertiary increase in corticosteroids for gillnetted fish between 24 and $48 \mathrm{~h}$ (Table 1) is similar to that reported for reciprocal striped bass hybrids (white bass, $M$. chrysops, $\times$ striped bass, Tomasso et al. 1980) and channel catfish (Ictalurus punctatus, Davis et al. 1984).

Based on information by Tomasso et al. (1980), it was felt that changes in plasma chlorides were not expected to be detectable until $24 \mathrm{~h}$ post-capture. However, this was not the case, as these fish demonstrated a loss of plasma chlorides almost immediately. The present findings were closer to those of Wedemeyer (1972) who found immediate development of hypochloremia in salmonids after the fish were netted and transferred to soft water.

It is apparent from these data that brood striped bass capture by electrofishing is, by far, the less stressful method of the two techniques examined. Although the recovery 
times were similar, up to $24 \mathrm{~h}$, only those fish collected by electrofishing approached a complete recovery with corticosteroid levels nearing baseline values.

Based on this information, culturists no longer need to "feel" that electrofishing is the method of choice of brood fish collection. Therefore, if given a choice that is economical and practical, collection of striped bass that are intended to be returned to the spawning river after spawning in a hatchery should be made by electrofishing. If electrofishing is not a viable alternative, then stress effects may possibly be mitigated through the use of salt and/or anesthetics in the hauling water or holding facilities. However, this mitigating possibility has not yet been evaluated for striped bass using the two capture techniques mentioned above.

\section{Acknowledgments}

This project was funded in part by the Maryland Department of Natural Resources, Tidewater Administration; the University of Maryland Center for Environmental and Estuarine Studies, Horn Point Environmental Laboratory; and the National Sea Grant College Program, NOAA, Department of Commerce to the Maryland Sea Grant College Sea Grant Extension Program. The U.S. Government is authorized to produce and distribute reprints for governmental purposes not withstanding any copyright notation that may appear hereon. The authors wish to thank Nick Parker, Mary Ann Suttle, and Rick Bennett for their assistance in the corticosteroid analysis, and Steve Early, Earl and Dale Dawson, Robert Miller, Joe Serafy, Haluk Tuncer, and Dan Theisen for their help in collecting the brood fish and blood samples. This study is listed as CEES Contribution Number 2222.

\section{Literature Cited}

Bennett, R. O. and R. C. Rhodes, III. 1986. Evaluation of oral administration of cortisol and metyrapone: The effects on serum cortisol in rainbow trout (Salmo gairdneri). Comparative Biochemistry and Physiology 83A:727-730.
Davis, K. B. and N. C. Parker. 1983. Plasma corticosteroid and chloride dynamics in rainbow trout, Atlantic salmon, and lake trout during and after stress. Aquaculture 32:189-194.

Davis, K. B., N. C. Parker and M. A. Suttle. 1982. Plasma corticosteroids and chlorides in striped bass exposed to tricaine methanesulfonate, quinaldine, etomidate, and salt. The Progressive Fish-Culturist $44: 205-207$.

Davis, K. B., M. A. Suttle and N. C. Parker. 1984. Biotic and abiotic influences on corticosteroid hormone rhythms in channel catfish. Transactions of the American Fisheries Society 123:414-421.

Esch, G. W. and T. C. Hazen. 1978. Thermal ecology and stress: a case history for red-sore diseases in largemouth bass. Pages 331-363 in J. Thorpe and J. Gibbons, editors. Energy and environmental stress in aquatic systems. U.S. Department of Energy Symposium Series Number 48. Publication Number CON-7711111. Springfield, Virginia, USA.

Fagerlund, U. M. H. 1970. Determining cortisol and cortisone simultaneously in salmonid plasma by competitive protein binding. Joumal Fisheries Research Board of Canada 17:596-601.

Gratzek, J. B. and R. Reinert. 1984. Physiological responses of experimental fish to stressful conditions. National Cancer Institute Monographs 65: 187-193.

Harrell, R. M. 1984. Review of striped bass brood stock acquisition, spawning methods and fry production. Pages $45-57$ in J. P. McCraren, editor. The aquaculture of striped bass: a proceedings. Maryland Sea Grant Publication UM-SG-MAP84-01. University of Maryland, College Park. Maryland, USA.

Harrell, R. M., J. H. Kerby and R. V. Minton, editors. 1990. Culture and propagation of striped bass and its hybrids. Striped Bass Committee, Southern Division. American Fisheries Society, Bethesda, Maryland, USA.

Lewis, S. D. 1971. The effect of salt solutions on osmotic changes associated with surface damage to the golden shiner, Notemigonus chrysoleuca. Dissertation Abstracts, Part B, Science and Engineering 31:6346.

Mazeaud, M. M., F. Mazeaud and E. M. Donaldson. 1977. Primary and secondary effects of stress on fish: some new data with a general review. Transactions of the American Fisheries Society 106:201212 .

McLeay, D. J. 1973. Effects of ATCH on the pituitary-interrenal axis and abundance of white blood cell types in juvenile coho salmon, (Oncorhynchus kisutch). General and Comparative Endocrinology 21:431-440.

Murphy, B. E. P. 1967. Some studies of the protein binding of steroids and their application to the routine micro and ultramicro measurements of 
various steroids in body fluids by competitive protein binding radioassay. Journal of Clinical En docrinology 27:973-990.

SAS (Statistical Analysis Systems Institute, Inc.). 1985. SAS user's guide: Basics, version 5 edition. SAS, Cary, North Carolina, USA.

Schreck, C. B. 1976. The stress concept in fisheries: Implications in environmental monitoring. Proceedings of the Western Association of State Game and Fish Commissioners 56:186-188.

Seyle, H. 1950. Stress and the general adaptation syndrome. Journal of British Medicine 1:13831392.

Sokal, R. R. and F. J. Rohlf. 1982. Biometry, 2nd edition. W. H. Freeman, San Francisco, California, USA.

Tomasso, J. R., K. B. Davis and N. C. Parker. 1980. Plasma corticosteroid and electrolyte dynamics of hybrid striped bass (white bass $\times$ striped bass) during netting and hauling. Proceedings of the World Mariculture Society 11:303-310.

Wedemeyer, G. 1970. The role of stress in disease resistance of fishes. Pages 30-35 in S. F. Snieszko, editor. A symposium on diseases of fishes and shellfishes. American Fisheries Society, Bethesda, Maryland, USA.

Wedemeyer, G. 1972. Some physiological consequences of handling stress in the juvenile coho salmon (Oncorhynchus kisutch) and steelhead trout (Salmo gairdneri). Journal of the Fisheries Research Board of Canada 29:1780-1783.

Wedemeyer, G. A. and D. J. McLeay. 1981. Method for determining the tolerance of fishes to environmental stressors. Pages $247-276$ in A. D. Pickering, editor. Stress and fish. Academic Press, London, England.

Yeager, D. M., J. E. Van Tassel and C. M. Wooley. 1990. Collection, transportation, and handling of striped bass brood stock. Pages $29-42$ in R. M. Harrell, J. H. Kerby and R. V. Minton, editors. Culture and propagation of striped bass and its hybrids. Striped Bass Committee, Southern Division, American Fisheries Society, Bethesda. Maryland, USA. 